Araştırma Makalesi
Adıaman Üniversitesi
Mühendislik Bilimleri Dergisi
$15(2021) 498-507$

\title{
INVESTIGATION OF THE STRUCTURAL TRENDS THROUGH AEROMAGNETIC DATA FOR THE CENTRAL ANATOLIAN CRYSTALLINE COMPLEX (KIRSEHIR BLOCK), TURKEY
}

\author{
Ezgi ERBEK KIRAN ${ }^{1 *}$ \\ ${ }^{1}$ Department of Geophysical Engineering, Faculty of Engineering, Suleyman Demirel University, , Isparta, 32260, Turkey \\ Geliş Tarihi/Received Date: 17.09.2021 Kabul Tarihi/Accepted Date: 12.12.2021 DOI: 10.54365/adyumbd.997085
}

\begin{abstract}
The main goal of this study is to delineate the subsurface structural features and depths of the causative sources in the Central Anatolian Crystalline Complex (Kirsehir Block), Turkey from aeromagnetic data. To this end, spectral analysis technique, analytic signal (AS) and tilt angle method were applied to the aeromagnetic data. The depths of causative sources were founded to vary between $8.48 \mathrm{~km}$ and $1.60 \mathrm{~km}$. The AS and tilt angle method was implemented to regional anomalies and it was seen that the geological units defined by the field observation have a deeper root below the surface. In addition, although there are no rocks that have magnetic properties in the center of the geological map, the existence of a magnetized structure in the tilt map was determined. This phenomenon can be evaluated as the existence of a highly magnetized unit in the region that may have been covered by continental clastic rocks.
\end{abstract}

Keywords: Analytic signal, tilt-depth method, aeromagnetic dat

\section{TÜRKİYE İÇ ANADOLU KRISTALİN KOMPLEKSI (KIRŞEHİR BLOK) IÇIN AEROMAGNETIK VERILERLE YAPISAL TRENDLERININ INCELENMESI}

\section{ÖZET}

$\mathrm{Bu}$ çalışmanın temel amacı, Türkiye'deki Orta Anadolu Kristalin Kompleksindeki (Kırşehir Bloğu), bozucu kaynakların yer altı yapısal özelliklerini ve derinliklerini aeromanyetik verilerden belirlemektir. Bu amaçla aeromanyetik verilere spektral analiz tekniği, analitik sinyal (AS) ve tilt açısı yöntemi uygulanmıştır. Bozucu kaynakların derinliklerinin 8,48 km ile 1,60 km arasında değiştiği tespit edilmiştir. AS ve tilt açısı yöntemi bölgesel anomalilere uygulanmış ve saha gözlemiyle tanımlanan jeolojik birimlerin yüzeyin altında daha derin bir köke sahip olduğunu görülmüştür. Ayrıca jeolojik haritanın merkezinde manyetik özelliklere sahip kayaçlar olmamasına rağmen tilt haritasında manyetize bir yapının varlığı tespit edilmiştir. Bu olgu, bölgede kıtasal kırıntılı kayaçlarla kaplanmış olabilecek yüksek oranda manyetize olmuş bir birimin varlığı olarak değerlendirilebilir.

Anahtar Kelimeler: Analitik sinyal, Tilt- derinlik yöntemi, havadan manyetik veri

\section{Introduction}

The magnetic method has been widely used in exploration of oil-gas and geothermal region, detection of location masses of igneous rocks and faults, definition of near-surface volcanic rocks, recognition of the subsurface and surface. Besides those, the aforementioned technique allows the investigation of outcropped or buried magmatic rocks (containing high susceptibility) and their position/geometry. As well-known, this method is based on the Earth's magnetic fields and it measures the variation of the magnetic susceptibility in geological units. However, the interpretation of results

\footnotetext{
* e-posta: ezgierbek@sdu.edu.tr ORCID ID: https://orcid.org/0000-0003-4627-8932
} 
acquired through this method is much more complicated than the other geophysical techniques due to the dipolar nature of the magnetic field and body magnetizations. To eliminate these effects, various techniques have been developed by researchers. One of them is Reduce to Pole correction (RTP) developed by Baranov [1] and it was later improved by Ansari and Alamdar [2]. The method aims to give the exact locations of the magnetic sources caused by the anomaly. The other major techniques, which allow researchers to define the boundaries of the structures, can be listed as Euler (EU) Deconvolution [3], analytic signal (AS) [4], tilt angle derivative [5], total horizontal derivative of the tilt angle [6] and normalized standard deviation [7].

The study region bounded by Longitudes $33.5^{\circ} \mathrm{E}-35.0^{\circ} \mathrm{E}$ and Latitudes $38.5^{\circ} \mathrm{N}-40.0^{\circ} \mathrm{N}$ in the central Anatolian Crystalline complex (Kirsehir Block), Turkey (Figure 1) has complex geological and tectonic backgrounds. Considering those, many studies have been carried out in the region. For example, Okay [8] examined the high-pressure/low-temperature metamorphic rocks in this Massif. The volcanic vents and geodynamics properties were observed by Dhont et al. [9.] Kadioglu et al., [10] interpreted the gabbroic rocks in Agacoren Granitoid (located in the Kursehir Massif) using field observation and aeromagnetic data Akın and Ciftci [11] investigated the distribution of heat flow and radiogenic heat production in this region. Lefebvre et al. [12] searched Late Cretaceous extensional denudation around Kirsehir Massif. Van Hinsbergen et al. [13] and Cinku et al. [14] exhibited tectonic evolution and paleogeography of the Kirsehir Block and central Anatolia. In addition to these geological and tectonic surveys, the area has important metallic mineral and iron-bearing minerals. This phenomenon deserves a further analysis because the studies carried out in the literature are limited. Therefore, the paper aims to delineate the exact locations of the magnetic sources, their elongation, and linear structures caused by the high magnetic anomalies in the Kirsehir Block using the above-mentioned methods.

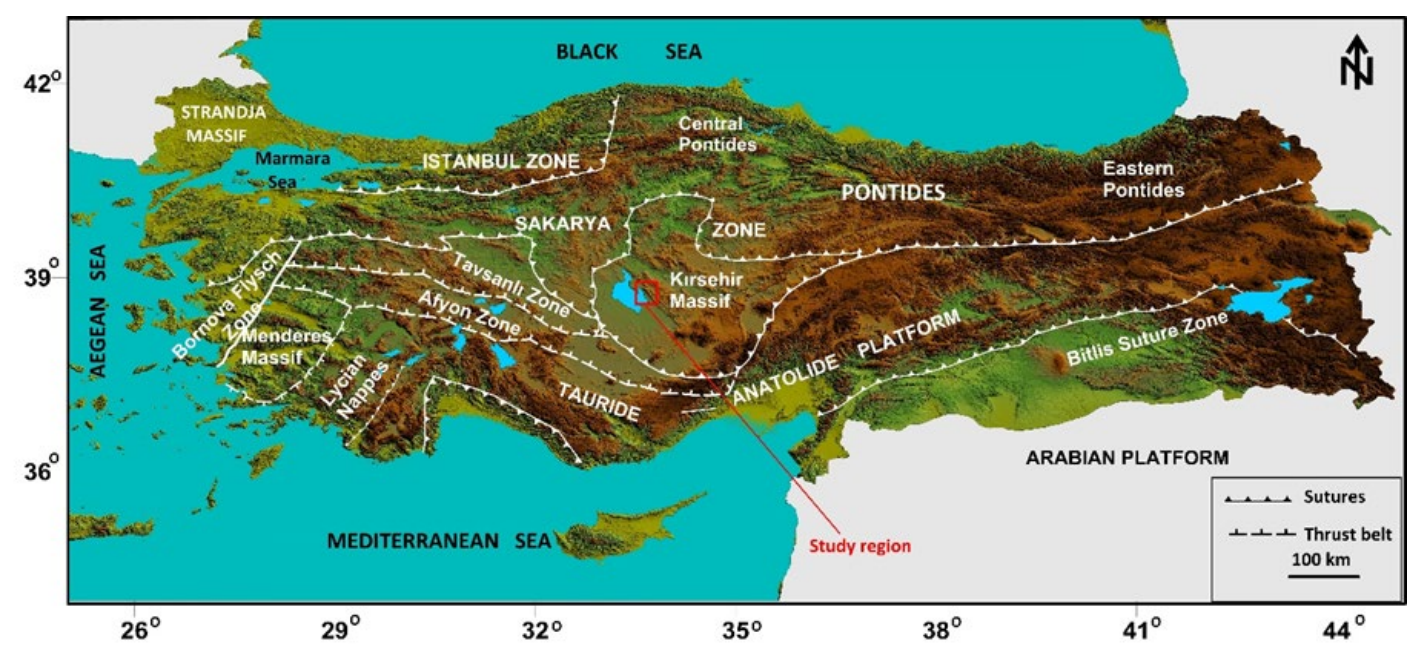

Figure 1. A Simplified tectonic map showing major tectonic units in the central Anatolia and its vicinity (from [15]). Red rectangle shows the study region

\section{Geo-Tectonic Settings}

The present tectonic structure of Anatolia was shaped by the Pan-African, Hercynian, Kimmerid and especially Alpid mountain formation phases, and was later modified by neo-tectonic movements [16]. After the closure of the Tethys Ocean, the North and South Anatolian Fault zones were formed as a result of the NS-trending compression and after the compression, escape tectonics started in Anatolia $[16,17]$. The Kirsehir Block situated in the central Anatolia (Turkey) is triangular crystalline massif of continental origin and it shares the boundary with the Salt Lake fault zone at the west, the East Anatolian Fault Zone at the east, the North Anatolian Fault Zone at the north and the Anatolide-Tauride Platform at the south. The region was defined as a metamorphic belt with Cretaceous aged [18] and it has been 
affected by deformation and volcanism $[9,17,18]$. Also, the region was exposed to plutonic activities during Upper Cretaceous - Eocene period and the geological units were characterized by abundant granitoid and syenites with the Upper Cretaceous - Paleocene aged. These granitoid series extend along the Salt Lake (Tuz Gölü) with NW-SE direction.

The region is generally described by the low pressure, high temperature conditions. The geological units contain the high-temperature metamorphic rocks and igneous intrusions with Late Cretaceous aged $[12,13,19,20]$. The basement of the block is composed of metamorphic rocks and the ophiolitic units overlaid on the basement. In addition, the basement rocks were cut by the magmatic intrusive rocks in the region. Volcano-sedimentary and sedimentary series with Eocene aged is also covered with the metamorphic and the magmatic units [11]. Ophiolitic series located at the NW and NE part of the Kirsehir Block could be associated with the İzmir-Ankara-Erzincan Suture Zone. Volcanic series with Late Cretaceous aged (like agglomerate, sandstone, tuff, radiolarite, pelagic limestone, basaltic andesitic pillow lava) are situated at the southern part of the region and they reach out along the E-W trending $[11,21]$.

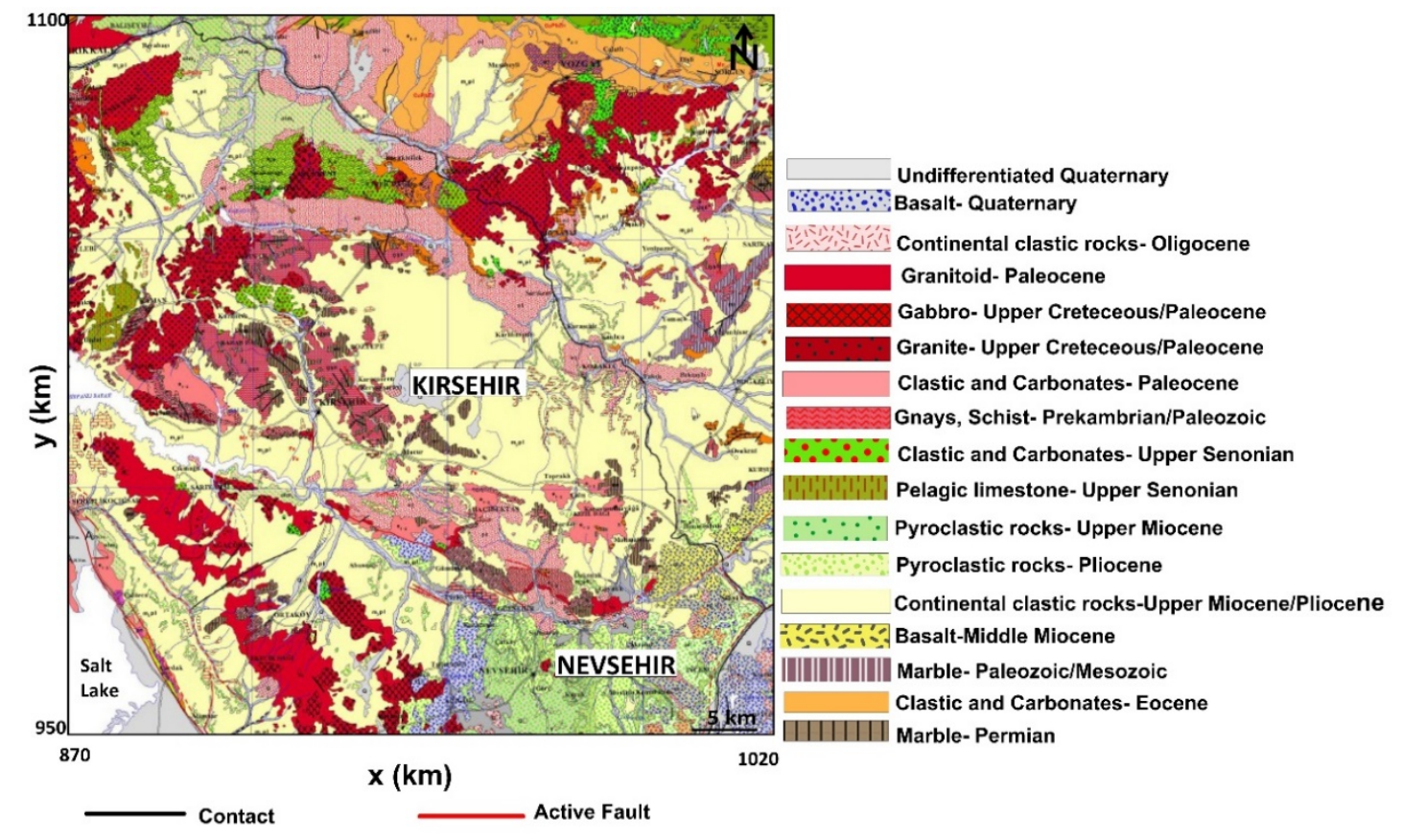

Figure 2. Geological map of the study region (modified from 1/500000 digital geological maps database of Mineral Research and Exploration General Directorate (MTA), [22]).

Many geophysical studies determined the structure of the crust have been carried out in the central Anatolia. Using the dispersion of love waves, the average thickness of the crust in Anatolia was found to be $31 \mathrm{~km}$ by Canitez et al., [23] while Genc et al. [24] calculated the average crustal thickness as 35 $\mathrm{km}$ for the northern part of Central Anatolia utilizing spectral analysis of the gravity anomalies. Also, the crustal thickness of the central Anatolia was computed to be approximately $34 \mathrm{~km}$ by using aeromagnetic, gravity and deep seismic reflection data in the study conducted by Ates et al. [25]. Besides those, Ates et al. [26] discovered the Curie point depths (7.9 - $22.6 \mathrm{~km})$ of the Central Anatolia.

\section{Material and Method}

Aeromagnetic data with 2-arc-minute resolution (EMAG 2) used in this study are supplied from National Centers for Environmental Information (NOAA). Those data are compiled from satellite, ship, and airborne magnetic measurements. These data have been recorded at an altitude of $4 \mathrm{~km}$ above sea level. They provide valuable information for observing anomalies in the continental crust, areas of large- 
scale volcanism, and highly magnetized rocks. Other technique information was given by Maus et al. [27]. The variation of magnetic amplitudes was given in Figure $3 \mathrm{a}$ and the map shows that the values vary from -563 to $+605 \mathrm{nT}$. To eliminate the undesired effects caused by the dipolar nature of earth, reduce to pole (RTP) correction was applied to aeromagnetic data. During the correction, the inclination angle was computed as $56.7^{\circ}$ while the declination angle was taken as $4.2^{\circ}$. The map obtained via RTP correction is seen in Figure $3 \mathrm{~b}$ and the areas with the low magnetization and non-magnetizing rocks are represented by dark blue, and green tones whereas the rocks containing the minerals with the magnetization feature (especially gabbro etc.) are represented by red and pink colors. Especially, gabbroic rocks display high magnetization in the region.

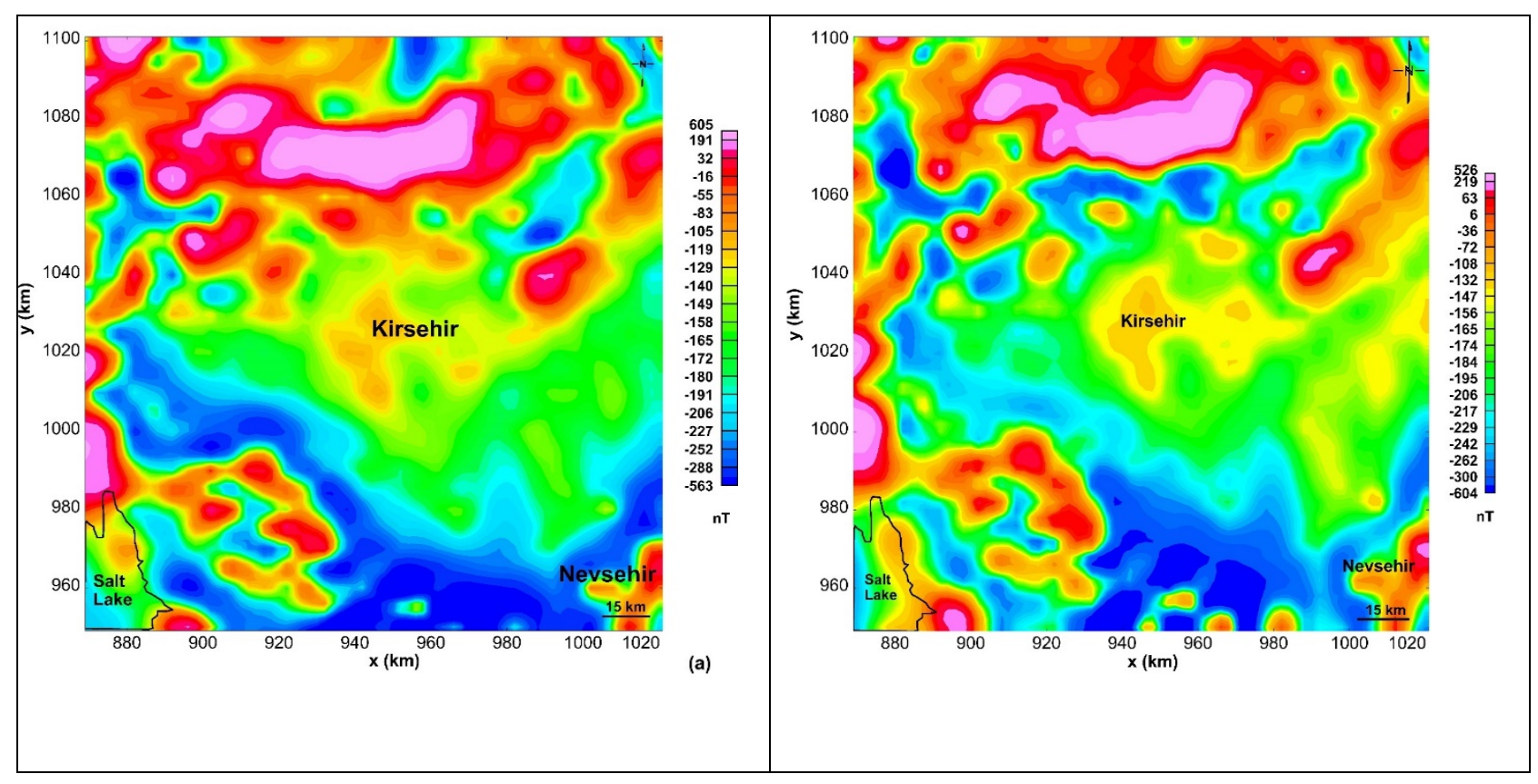

Figure 3. a) The distribution of aeromagnetic data of the study region, b) RTP anomaly map of the study area

\subsection{Radially averaged power spectrum technique (RAPS)}

Spector and Grant [28] suggested the basic 2-D spectral analysis method that is based on the spectral analysis (power spectrum curve) of the data. This method is widely used to determine the average depth of the causative sources, the depths of the volcanic intrusions and the basement complex and the subsurface geological structures. The technique shows the relationship between the spectrum of the magnetic data and the depth extend of the magnetic body by transforming spatial data into the frequency domain and Shuey et al. [29] pointed out that the method gives better results on regional anomalies.

In this study, the RAPS technique was applied to RTP magnetic data in the frequency domain and the results are plotted RAPS versus wavenumber $(\mathrm{k})$. The slope of the plotted graphic displays the average depth of each segment (Fig. 4) and the depth is calculated by using Eq. (1).

$$
\text { depth }=-\frac{\text { Slope }}{4 \pi}
$$




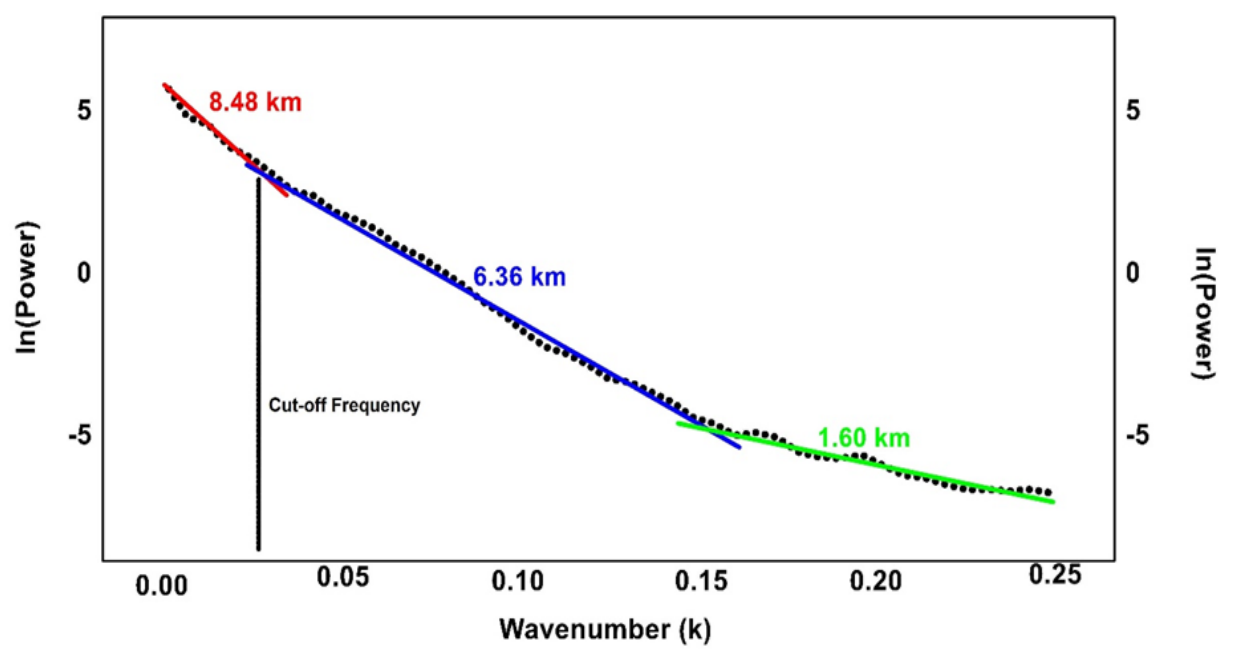

Figure 4. Radially average power spectrum and depth estimate of RTP aeromagnetic data of the Study area. Power spectrum of aeromagnetic data showing the represent the depths of regional and residual anomalies.

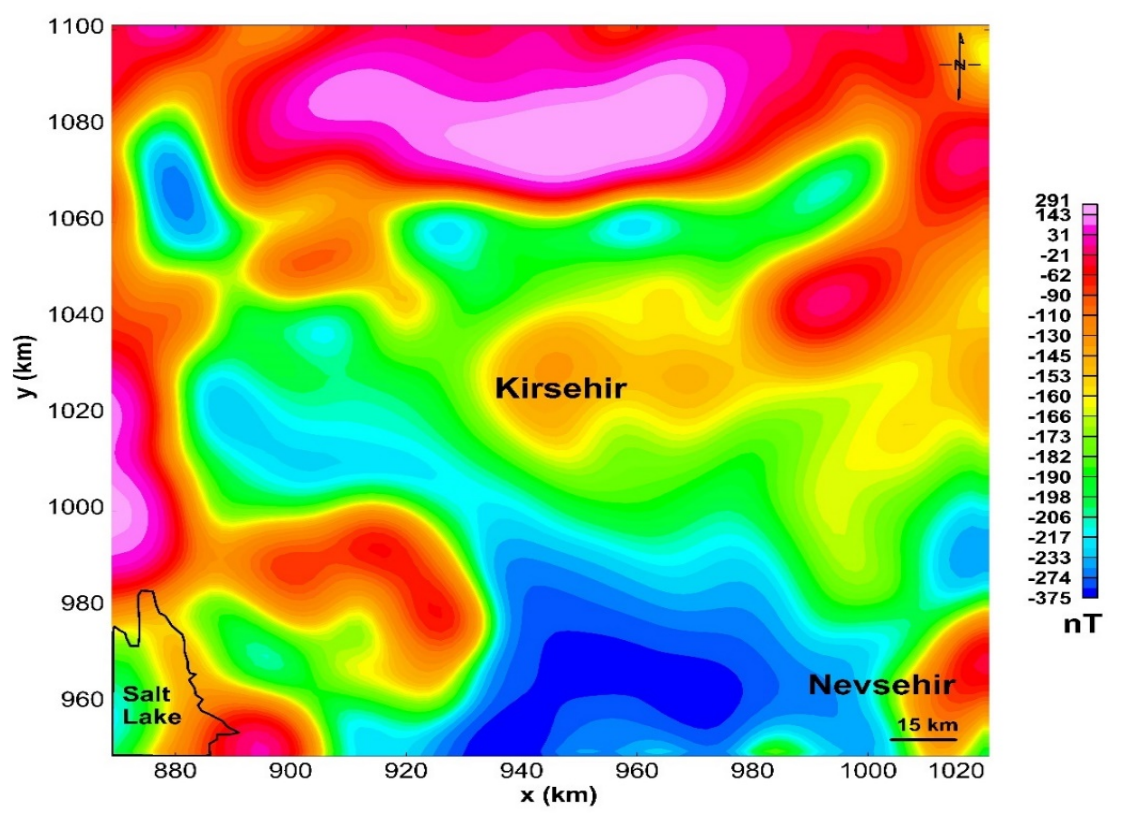

Figure 5. The regional anomaly (High-pass filtered with cut-off frequency $(\mathrm{k})=0.03 \mathrm{cycle} / \mathrm{km}$ ) map of the study region

The graphic can be divided into three segments for this study. First segment is represented the depth for the deep magnetic sources below the ground surface and its depth was computed as $8.48 \mathrm{~km}$ while second one corresponds to the depth of intermediate magnetized bodies and it was calculated as $6.36 \mathrm{~km}$. The third segment represents the average depth of the shallow sources located in the region and it was estimated as $1.60 \mathrm{~km}$. As well-known, the magnetic anomalies have two components including the regional (deep magnetized bodies) and residual anomalies (shallow magnetized bodies). In order to emphasize the effects caused by the shallow sources in the map, the high-pass filter technique was applied to the RTP data by utilizing the cut-off number $(0.03 \mathrm{cycle} / \mathrm{km})$ obtained from the analysis of RAPS. Hereby, the resulting high-pass filtered map was illustrated in Fig. 5. According to the map, the high magnetic anomalies are located at the northern and southwestern parts of the map trending E- 
W and NW-SE, respectively (Fig 5). These anomalies can be associated with the existence of the gabbroic and granodiorite units seen in the geologic map (see Fig. 2).

\subsection{Analytic Signal}

Analytic signal method, which is widely used to estimate the depth and location of the causative sources, is successfully applied to the data because of the independence of magnetization direction. The 2-D AS was firstly defined by Nabighian [30] and the technique was later improved to the 3-D by Nabighian [31]. The method was based on the derivatives of the potential field data (magnetic data or gravity data) in the $\mathrm{x}, \mathrm{y}$ and $\mathrm{z}$ directions by Roest et al. [4] and it is given as follows:

$$
A S=\sqrt{\left(\frac{\partial f}{\partial x}\right)^{2}+\left(\frac{\partial f}{\partial y}\right)^{2}+\left(\frac{\partial f}{\partial z}\right)^{2}}
$$

where $\mathrm{f}$ is the total magnetic anomaly. $\frac{\partial f}{\partial x}, \frac{\partial f}{\partial y}$, and $\frac{\partial f}{\partial z}$ is the derivatives of the magnetic field in the $\mathrm{x}$, $y$ and z-directions, respectively. The locations of the maximum AS can be used to detect the outlines of the magnetic sources. The AS map produced from the regional anomalies is indicated in Figure 6. According to the map, the AS solutions of the magnetic anomalies were observed at many parts of the study area in the northern and southern parts and the regions indicated the locations of the rocks with high magnetic response (Gabbro, granitoid rocks).

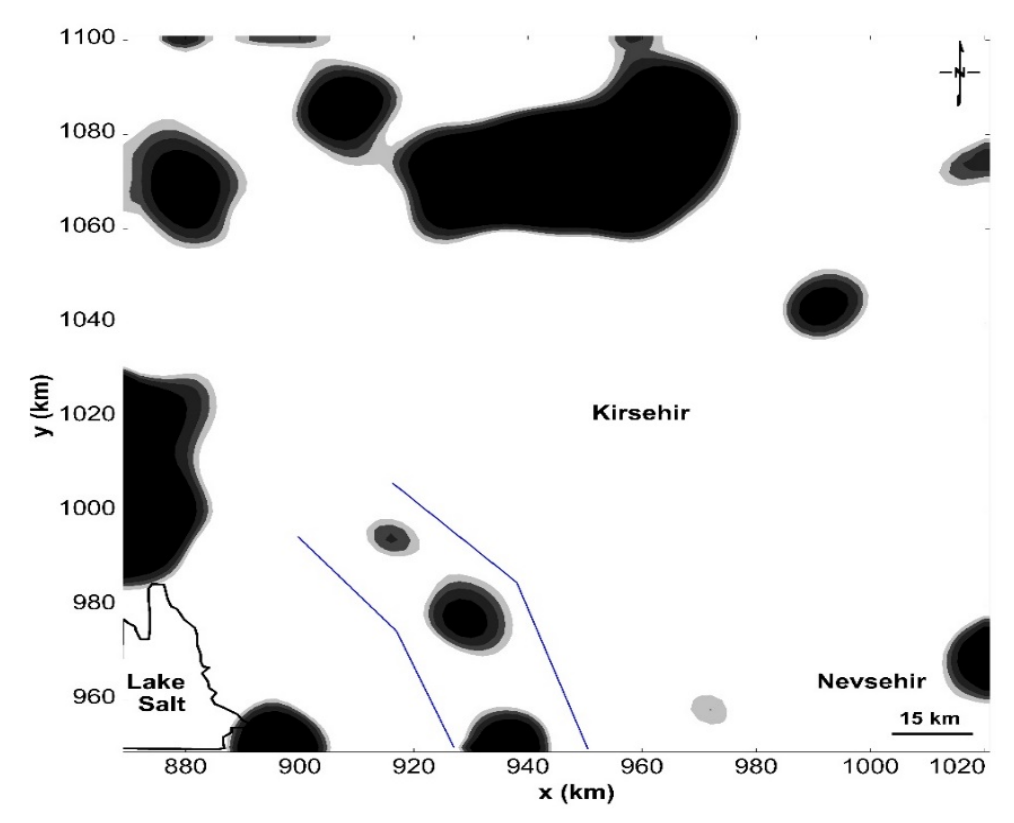

Figure 6. The map shows the analytic signal (AS) map applied to RTP data. Black patches indicate the maximum values of AS. The blue line shows the direction of extension of the structures.

\subsection{Tilt angle method}

The tilt angle derivative (Tilt) method is a useful tool delineate the trends/contacts region and boundaries of the magnetized sources. The method is developed by Miller and Singh [5], as seen in Eq. 2. 
The amplitudes of the Tilt vary between $-\pi / 2$ to and $+\pi / 2$ due to the arctangent trigonometric function. The Tilt displays positive amplitudes $(+0.785)$ over the magnetized bodies while the negative amplitudes $(-0.785)$ are also located outside of the magnetized bodies. Also, the zero contours passed through over the edges of the structures show the boundaries of bodies.

$$
\text { Tilt }=\arctan \left[\frac{\frac{\partial T}{\partial z}}{\sqrt{\left(\frac{\partial T}{\partial x}\right)^{2}+\left(\frac{\partial T}{\partial y}\right)^{2}}}\right]
$$

The method which is called the tilt-depth method was then improved by Salem et al. [32] in order to estimate the upper depth of the interpreted contact. The upper depth for the sources is estimated by using the distance between $\pm \pi / 2$ Radians $\left( \pm 45^{\circ}\right)$ contours. Due to not require any geological information, it has an advantage in the estimation of depth [33].

Table 1. The depths to top of the magnetized bodies obtained from the tilt-depth method.

\begin{tabular}{|clc|}
\hline & \multicolumn{2}{c|}{ Tilt-Depth $(\mathbf{k m})$} \\
Structure & West Edge & East Edge \\
\hline A & $6.7 \mathrm{~km}$ & $4.4 \mathrm{~km}$ \\
\hline $\mathrm{B}$ & $4.6 \mathrm{~km}$ & $6.5 \mathrm{~km}$ \\
\hline $\mathrm{C}$ & $3.5 \mathrm{~km}$ & $4.3 \mathrm{~km}$ \\
\hline $\mathrm{D}$ & $5.7 \mathrm{~km}$ & $2.1 \mathrm{~km}$ \\
\hline $\mathrm{E}$ & $5.3 \mathrm{~km}$ & $7.7 \mathrm{~km}$ \\
\hline $\mathrm{F}$ & $3.6 \mathrm{~km}$ & $4.4 \mathrm{~km}$ \\
\hline
\end{tabular}

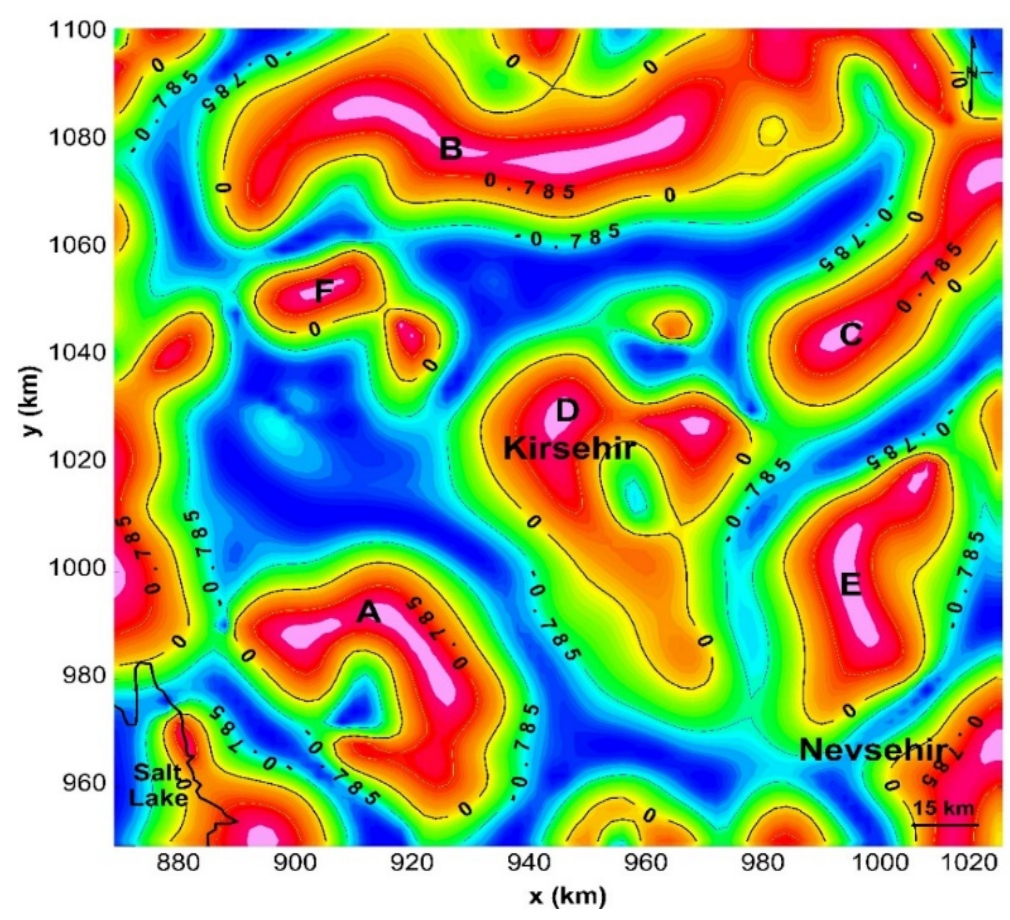

Figure 7. The Tilt map of the study region. Black lines show the zero contour. 
By a closer look at Fig. 7, six regions that display high magnetization were observed on the Tilt map (these regions were marked as A, B, C, D, E, and F on the map). In this map, zero contours show the boundaries of the magnetized bodies, and the upper depths of these structures were estimated using the Tilt-depth method (Table 1). It is provided to calculate the upper depth of deep-seated sources in the region clearly utilizing this method. Also, it is shown that these depth estimates are in accordance with the average depth values obtained from power spectrum analysis.

\section{Conclusions}

This paper aimed to determine structural trends of the Central Anatolian Crystalline Complex (Kirsehir Block), Turkey from aeromagnetic data. To reach these goals, spectral analysis technique, AS method, and Tilt angle method were applied to the aeromagnetic data and the average depths of the regional and residual anomalies were found to be $8.48 \mathrm{~km}$ and $1.60 \mathrm{~km}$ respectively. In addition, to determine the exact location of the causative sources, AS method was executed to the RTP data. The signal exhibited the maximum value over the causative sources (Fig. 6). As it can be seen from the AS map, maximum magnetization contrasts were observed at northern and southern parts. The strong anomalies located in the northern part of the map display nearly trending E-W whereas the trends of the other anomalies located in the south reach out NW-SE direction. Also, the boundaries of the six magnetized bodies located in the study region and their upper depth were calculated using the tilt method. This method showed that although there are no rocks that have magnetic properties in the center of the geological map, the existence of a magnetized structure in the tilt map was determined as a result of the methods applied. This phenomenon can be evaluated as the existence of a highly magnetized unit in the region that may have been covered by continental clastic rocks. Thus, the determination of the region requires special attention. With sufficient effort in the future, detailed geochemical/geophysical surveys and core drilling could be performed in this region and the structure can be defined.

\section{Acknowledgment}

The author thanks the National Centers for Environmental Information (NOAA) for the provision the magnetic data.

\section{Kaynaklar}

[1] Baranov V. A new method for interpretation of aeromagnetic maps: Pseudo-gravimetric anomalies. Geophysics 1957; 22: 359-383.

[2] Ansari AH, Alamdar K. Reduction to the pole of magnetic anomalies using analytic signal. World Applied Sciences Journal 2009; 7(4): 405-409.

[3] Reid AB, Allsop JM, Granser H, Millett AJ, Somerton IW. Magnetic interpretation in three dimensions using Euler Deconvolution. Geophysics 1990; 55: 80-90.

[4] Roest WR, Verhoef J, Pilkington M. Magnetic interpretation using the 3-D analytic signal. Geophysics 1992; 57(1): 116-125.

[5] Miller HG, Singh V. Potential field tilt-a new concept for location of potential field sources. Journal of Applied Geophysics 1994; 32: 213 - 217.

[6] Verduzco B, Fairhead JD, Green CM, MacKenzie C. New insights into magnetic derivatives for structural mapping. The Leading Edge 2004; 23: 116-119.

[7] Cooper GRJ, Cowan DR. Enhancing potential field data using filters based on the local phase. Computers \& Geosciences 2006; 32: 1585-1591.

[8] Okay AI. High pressure/low temperature metamorphic rocks of Turkey. Geol. Soc. Amer. Mem. 1986; 164: 333-348.

[9] Dhont D, Chorowicz J, Yurur T, Froger JL, Kose O, Gundogdu N. Emplacement of volcanic vents and geodynamics of Central Anatolia, Turkey. J. Volcan. Geother. Res. 1998; 85: 33-55. 
[10] Kadioglu, Y.K., Ates, A., and Gulec, N. Structural interpretation of gabbroic rocks in Agacoren Granitoid, central Turkey: field observations and aeromagnetic data. Geol. Mag. 1998; 135(2), $245-$ 254.

[11] Akin U, Ciftci Y. Heat flow of the Kırşehir Massif and geological sources of the radiogenic heat production. Bulletin of the Mineral Research and Exploration 2011; 143: 53-72.

[12] Lefebvre C. The tectonics of the Central Anatolian Crystalline Complex: A structural, metamorphic and paleomagnetic study. in Utrecht Studies in Earth Sciences 2011; 3, 147 p., Utrecht Univ.

[13] Van Hinsbergen DJJ, Maffione M, Plunder A, Kaymakc1 N, Ganerød M, Hendriks BWH, Corfu F, Gurer D, Gelder GINO, Peters K, Mcphee P, Brouwer F, Advokaat E, Vissers R. Tectonic evolution and paleogeography of the Kırşehir Block and the Central Anatolian Ophiolites, Turkey. Tectonics 2016; 35(4): 983-101.

[14] Cinku MC, Hisarli ZM, Yilmaz Y, Ulker B, Kaya, Oksum E, Orbay N, Ozbey ZU. The tectonic history of the Niğde-Kirşehirmassif and the Taurides since the Late Mesozoic: Paleomagnetic evidence for two-phase orogenic curvature in Central Anatolia. Tectonics 2016; 35, 772-811, doi:10.1002/2015TC003956.

[15] Okay AI, Tuysuz O. Tethyan sutures of northern Turkey. In: Durand B, Jolivet L, Horváth F, Séranne M. (Eds.), The Mediterranean Basins: Tertiary Extension Within the Alpine Orogen. Geological Society, London, Special Publications 1999; 156: 475-515.

[16] Sengor AMC. Cimmeriden orogenic system and tectonics of Eurasia. Geological Society of America, Special Publication 1984; 195: 82.

[17] Sengor AMC, Gorur N, Saroglu F. Strike-slip faulting and related basin formation in zones of tectonic escape: Turkey as a case study: in Biddle, K.T. and Christie-Blick, N., edts, Strike-slip Deformation, Basin Formation, and Sedimentation. Soc. Econ. Paleont. Min. Spec. Pub. 1985; 37: 227-264.

[18] Pasquare G, Poli S, Vezzoli L, Zanchi A. Continental arc volcanism and tectonic setting in Central Anatolia, Turkey. Tectonophysics 1988; 146: 217-230.

[19] Whitney DL, Dilek Y. Metamorphism during alpine crustal thickening and extension in central Anatolia, Turkey: The Nigde metamorphic core complex. Journal of Petrology 1998; 39 (7): 13851403.

[20] Lefebvre C, Peters K, Wehrens P, Brouwer FM, Van Roermund HLM. Thermal and extensional exhumation history of a high-temperature crystalline complex (Hurkadag Massif, Central Anatolia). Lithos 2015; 238:156-173.

[21] Goncuoglu MC. Geologic des westlichen Nigde massivs; PhD Thesis, Bonn University, 1977; 181 pp.

[22] MTA, 2002. 1/500000 digital geological maps database of Mineral Research and Exploration General Directorate, Ankara, Turkey.

[23] Canitez N. Structure of earth crust in North Anatolia by Gravity anomalies and seismology. PhD Thesis, Istanbul tecnical University 1962; 82 pp.

[24] Genc T, Tufan S, Sevinc A, Yemen H. Investigation of the crust structure of the North of Central Anatolia using Gravity and Magnetic Methods. 13th Geophysical Congress of Turkey, 1993; 110 pp.

[25] Ates A, Bilim F, Buyuksarac A. Curie Point Depth Investigation of Central Anatolia, Turkey. Pure appl. Geophys. 2005; 162: 357-371.

[26] Ates A, Bilim F, Buyuksarac A, Aydemir A, Bektas O, Aslan Y. Crustal Structure of Turkey from Aeromagnetic, Gravity and Deep Seismic Reflection Data. Surv Geophys 2012; 33: 869-885.

[27] Maus S, et al. EMAG2. A 2 arc min resolution Earth Magnetic Anomaly Grid compiled from satellite, airbone and marine magnetic measurements. Geochem, Geophys, Geosyst 2009; 10, Q08005. https://doi.org/10.1029/2009GC002471.

[28] Spector A, Grant FS. Statistical models for interpreting aeromagnetic data. Geophysics 1970; 35: 293-302.

[29] Shuey R, Schellinger D, Tripp A. Alley L. Curie depth determination from aeromagnetic spectra. Geophys. J. Int. 1977; 50 (1): 75-101. 
[30] Nabighian MN. The analytic signal of two-dimensional magnetic bodies with polygonal crosssection: its properties and use for automated anomaly interpretation. Geophysics 1972; 37: 507517.

[31] Nabighian MN. Toward a three dimensional automatic interpretation of potential field data via generalized Hilbert transforms: Fundamental relations. Geophysics 1984; 49(6): 780 -786.

[32] Salem A, Williams S, Fairhead JD, Ravat DJ, Smith R (2007) Tilt depth method: a simple depth estimation method using first-order magnetic derivatives. Leading Edge, 26 (12), 1489-1624

[33] Wang YG, Zhang J, Ge KP, Chen X, Nie FJ. Improved tilt-depth method for fast estimation of top and bottom depths of magnetic bodies. Appl. Geophys. 2016; 13: 249-256. https://doi.org/10.1007/s11770-016-0551-3. 